\title{
Variations in Mammary Metabolism During the Natural Filling of the Udder with Milk over a 12-h Period Between Two Milkings ${ }^{1}$
}

\author{
M. C. Thivierge, ${ }^{\star, 2}$ D. Petitclerc, $\dagger$ J. F. Bernier, ${ }^{*}$ \\ Y. Couture, $\uparrow$ and $H$. Lapierre† \\ *Département des sciences animales, Pavillon Paul-Comtois, \\ Université Laval, Sainte-Foy, QC, Canada, G1K 7P4 \\ †Dairy and Swine Research and Development Centre, \\ Agriculture and Agri-Food Canada, Lennoxville, QC, Canada, J1M 1 Z3 \\ †Faculté de médecine vétérinaire, Université de Montréal, \\ St-Hyacinthe, QC, Canada, J2S 7C6
}

\section{ABSTRACT}

Two groups of four Holstein cows, one in their second and the other in their third or fourth lactation, were used to study temporal variations of mammary metabolism over a 12-h period between two milkings. Blood samples were collected every 30 min from an artery and a mammary vein during a 12 -h interval between two milkings. Isoleucine, leucine, lysine, methionine, and phenylalanine mammary net fluxes varied or tended to change over time after milking with a similar pattern between whole blood and plasma. For these amino acids, whole blood and plasma net fluxes reached their maximum over the first $8 \mathrm{~h}$ after milking. Simultaneously, respiratory quotients decreased linearly and varied from 2.31 to 2.01 during the first $8 \mathrm{~h}$ of the period, suggesting active mammary lipogenesis. From 8 to $12 \mathrm{~h}$ after milking, mammary amino acid net fluxes decreased, while mammary oxygen uptake tended to increase with a concomitant decrease in the respiratory quotient reaching 1.84 to 1.40 . These findings suggest that, beginning $8 \mathrm{~h}$ after milking, mammary uptake of amino acids starts to decrease and catabolic processes appear promoted; this phenomenon could help to explain the increase in milk production reported in the literature with increased milking frequency.

(Key words: amino acid, mammary gland, uptake, nutrient)

Abbreviation key: AV = arteriovenous, $\mathbf{F I L}=$ feedback inhibitor of lactation.

Received July 2, 2001.

Accepted February 14, 2002.

Corresponding author: H. Lapierre; e-mail: lapierreh@em.agr.ca.

${ }^{1}$ Lennoxville Research Center contribution number 743; This work was partly supported by grants from the Natural Sciences and Engineering Research Council of Canada and the Fédération des producteurs de lait du Québec.

${ }^{2}$ Recipient of a scholarship granted by the Natural Sciences and Engineering Research Council of Canada.

\section{INTRODUCTION}

The synthesis of milk protein by the mammary gland appears to be regulated by at least two separate controls. One level of control is achieved through the adaptive capacities of the udder to maintain an adequate supply of precursors. Mammary adjustment of local blood flow rate to maintain the intracellular adenylate charge (Cant and McBride, 1995) is a good illustration of the adaptive capacity of the mammary gland. Similarly, a limitation in the supply of histidine was overcome by an increase in both mammary arterial blood flow and mammary removal of histidine (Bequette et al., 2000).

A second level of control has also been suggested. This control may be achieved in part by an inhibitory protein, the feedback inhibitor of lactation (FIL), which may regulate intramammary milk synthesis (Wilde et al., 1995). This protein inhibitor is synthesized within the mammary alveolar cells. Its regulatory effect on milk synthesis may occur through its accumulation in the alveolar space (Wilde et al., 1987) and, as FIL accumulates, the synthesis of nonlipid components may decrease and degradation of newly synthesized casein may increase (Wilde et al., 1987; Wilde and Peaker, 1990; Rennison et al., 1995). Also, the regulatory effect of FIL is distinct from the increased intramammary pressure as milk accumulates in the udder (Henderson and Peaker, 1984).

The 10 to $15 \%$ increment in milk yield resulting from increased milking frequency (Van Der Iest and Hillerton, 1989; Bar-Peled et al., 1995) suggests that mammary metabolism varies as milk accumulates in the udder between two milkings, even if a nutritional steady state is achieved by feeding cows every $2 \mathrm{~h}$. Also, variations in mammary metabolism over time need to be known to evaluate the use of short-term flux measurements across the mammary gland, which may be affected by the interval of time after milking at which they are taken. Therefore, to determine these variations, we monitored mammary metabolism during a 12 -h period after milking in high yielding Holstein cows. Mammary oxygen and $\mathrm{CO}_{2}$ 
exchanges, as well as glucose net uptake, were measured to monitor the temporal variation of mammary energy metabolism. Net fluxes of methionine, phenylalanine, tyrosine, leucine, isoleucine, lysine, and threonine were measured with both whole blood and plasma to determine whether the mammary uptake of amino acids is affected by time after milking.

\section{MATERIALS AND METHODS}

\section{Animals, Care, and Feeding}

Two groups of four Holstein cows, one in their second lactation and the other in their third or fourth lactation, were used to study the effect of time on mammary metabolism over a 12-h period between two consecutive milkings. Daily milk yield and BW averaged $29.2 \mathrm{~kg}$ (SEM 3.7 ) and $663 \mathrm{~kg}$ (SEM 17) for cows in second lactation and 36.1 (SEM 1.2) kg and $620 \mathrm{~kg}$ (SEM 45) for cows in third or fourth lactation. Days in milk, at the beginning of the experiment, were 199, 211, 217, and 234 for the second-lactation cows, and 62, 68, 111, and 129 for the third- or fourth-lactation cows. All cows were fitted with permanent catheters in the left external pudic artery and in the lateral branch of the cranial mammary vein, as described previously (Thivierge et al., 2000). An ultrasonic flow probe (Transonic Systems inc., Ithaca, NY) was placed around the left external pudic artery of all cows (Thivierge et al., 2000). Experimental procedures were approved by a local animal care committee and conducted according to the Canadian Council on Animal Care regulations (1993). Cows were allowed at least a 2wk recovery period after surgery before measurements began. One second-lactation cow had a substantial amount of feed refusals for a few days, including the day of blood sampling, which resulted in a reduction in milk yield by half. This cow was removed from statistical analyses, which therefore only included the remaining seven cows.

Animals were maintained in tie stalls equipped with rubber mats and bedded with straw. A TMR meeting nutritional requirements, providing $1.53 \mathrm{Mcal} / \mathrm{kg}$ of $\mathrm{NE}_{\mathrm{L}}$, $16.2 \% \mathrm{CP}$ (65\% RDP and 35\% RUP), $27.6 \% \mathrm{ADF}$, and $44.8 \%$ NDF (NRC, 1989) was fed in 12 equal daily meals. To maintain constant intake, cows were individually restricted at $95 \%$ of their preexperimental ad libitum intake. The TMR fed contained on a DM basis $37.7 \%$ corn silage $(8.2 \% \mathrm{CP} ; 23.0 \% \mathrm{ADF}$, and $41.3 \% \mathrm{NDF}), 37.7 \%$ grass silage (17.3\% CP; $29.9 \% \mathrm{ADF}$, and $45.9 \% \mathrm{NDF}$ ), $12.2 \%$ ground corn, $9.9 \%$ soybean meal and vitamins and minerals supplement to meet or exceed requirements. Rumen-protected methionine (72 g/d; Mepron M85, Degussa-Hüls, Canada) was fed simultaneously with the TMR in 12 meals daily. Silage DM was determined weekly to maintain a constant ratio of ingredients. Cows were milked twice daily at 0700 and $1900 \mathrm{~h}$.

\section{Experimental and Sampling Procedures}

Temporal variation in mammary metabolism was studied over a 12 -h period between two consecutive milkings. On the day of measurement, evacuation of residual milk at the morning milking was completed by an intravenous oxytocin injection (10 IU, Oxytocin Injection U.S.P., Sanofi Santé Animale Inc., Victoriaville, QC, Canada). Starting 30 min after the completion of the morning milking, blood was withdrawn simultaneously from both arterial and mammary venous sites every 30 min for 12 $\mathrm{h}$. The last blood sampling was followed by the evening milking, which was also completed by an intravenous oxytocin injection (10 IU). Arterial blood flow was continuously recorded every second, starting at least $15 \mathrm{~min}$ before the morning milking and ending 15 to $30 \mathrm{~min}$ after the end of the evening milking. We ensured that the cows were standing up for at least 5 min before each blood sampling. Milk was sampled at four consecutive milkings, which included two samples on the blood sampling day and two samples taken on the previous or following day, according to the schedule of the determination of $\mathrm{CO}_{2}$ production. Milk samples were kept frozen at $-20^{\circ} \mathrm{C}$ until analyses. Kinetics of $\left[1-{ }^{13} \mathrm{C}\right]$ leucine were simultaneously quantified over the 12 -h period at the whole body level and across the mammary gland, and results are reported elsewhere (Thivierge et al., 2002).

\section{Sample Processing and Laboratory Analyses}

After collection, blood samples were immediately placed on ice until processing. Samples for $\mathrm{pO}_{2}, \mathrm{pCO}_{2}$, and $\mathrm{pH}$ measurements were taken into heparinized syringes (Monovette Sarstedt, Aktiegesellschaft \& Co, Germany) and analyzed immediately on fresh blood using a $\mathrm{pH} /$ blood gas analyzer (model IL 1306, Instrument Laboratory, Lexington, MA). The packed cell volume of blood was determined by the microhematocrit method (Strumia et al., 1954). A whole blood sample (1 g) was weighed and $1 \mathrm{~g}$ of an internal standard hemolyzing solution was added for quantification of methionine, phenylalanine, tyrosine, leucine, isoleucine, lysine, and threonine (Calder et al., 1999). Arginine and histidine were not analyzed because of some analytical problems, and valine was not quantified because we considered that leucine and isoleucine would adequately represent the branched-chain amino acids. The standard solution was prepared using the following labeled amino acids diluted in $0.1 \mathrm{~N} \mathrm{HCl}$ to yield the concentrations given in parentheses $(\mu \mathrm{g} / \mathrm{g})$ : DL- $\left[1-{ }^{13} \mathrm{C}\right]$ Met (3.32), L- $\left[1-{ }^{13} \mathrm{C}\right]$ Phe (7.96), L- $\left[{ }^{15} \mathrm{~N}\right] \mathrm{Tyr}(9.92)$, L-[1- $\left.{ }^{13} \mathrm{C}\right] \mathrm{Leu}(23.77), \mathrm{L}-\left[{ }^{15} \mathrm{~N}\right] \mathrm{Ile}$ (18.75), 
DL- $\left[2-{ }^{15} \mathrm{~N}\right]$ Lys $(14.68), \mathrm{L}-\left[{ }^{15} \mathrm{~N}\right] \mathrm{Thr}$ (11.18). Labeled amino acids (95 to 99 Atom \%) were supplied by CDN Isotopes (Pointe-Claire, QC, Canada) for leucine, lysine, methionine, phenylalanine and isoleucine, threonine and tyrosine by Cambridge Isotope Laboratory (Andover, MA). Aliquots of whole blood were also kept for hemoglobin analysis. Blood samples for hemoglobin and amino acid measurements were kept frozen at $-20^{\circ} \mathrm{C}$ until analyses.

Plasma was obtained from centrifugation of the remaining whole blood at $3000 \times g$ for $15 \mathrm{~min}$ at $4^{\circ} \mathrm{C}$. Plasma samples $(1 \mathrm{~g})$ were weighed and $0.2 \mathrm{~g}$ of an internal standard solution was added for determination of methionine, phenylalanine, tyrosine, leucine, isoleucine, lysine, and threonine. The standard solution used for plasma amino acid quantification was prepared similarly to that used for whole blood amino acid quantification, but with five times higher concentration of each amino acid. Plasma aliquots were kept separately for glucose analysis. Plasma samples were kept frozen at $-20^{\circ} \mathrm{C}$ until analyses.

Whole blood samples for quantification of hemoglobin and the seven amino acids and plasma samples for glucose analysis were analyzed individually, resulting in 24 samples per sampling site per cow. Every four consecutive measurements were averaged to give six values, each representing a 2 -h period. Plasma samples for amino acid quantification were pooled hourly before the analysis; therefore, 12 samples were analyzed per sampling site per cow. Once again, every two consecutive 1-h pooled samples were averaged to give six values, each representing a 2-h period.

Whole blood and plasma amino acid isotopic enrichment of the background and processed samples were determined after deproteinization with sulfosalicylic acid and derivatization with $N$-(tert-butyldimethysilyl)- $N$ methyltrifluoroacetate-acetonitril by gas chromatography-mass spectrometry (Hewlett Packard model HP6890, S973 mass selective detector; Hewlett Packard, CA) as described by Calder and Smith (1988). Both whole blood and plasma amino acid concentrations were determined by isotopic dilution according to Calder et al. (1999). Glucose and hemoglobin concentrations were analyzed using colorimetric kits from Boehringer Mannheim (Dorval, QC, Canada).

\section{Calculations}

Concentration of blood oxygen was calculated from $\mathrm{pO}_{2}, \mathrm{pH}$ and hemoglobin concentration $(\mathrm{Hb} ; \mathrm{g} / \mathrm{L})$ according to Bartels and Harms (1959):

Normalized $\mathrm{pO}_{2}$ to standard $\mathrm{pH}$ of $7.4\left(\right.$ std $\left.\mathrm{pO}_{2}\right)$ :

$$
=\text { observed } \mathrm{pO}_{2} \times 10^{(-0.48 \times(7.4-\text { observed } \mathrm{pH}))}
$$

Hemoglobin saturation with $\mathrm{O}_{2}$ ( $\mathrm{Hb}$ satn; \%):

$$
=2.12548+95.70583 \times 10^{\left(-\left(-0.07456 \times\left(\mathrm{std}_{\mathrm{pO}}-25.78369\right)\right)\right)}
$$

This was then converted to milliliters of $\mathrm{O}_{2}$ per liter of blood using a factor of $1.34 \mathrm{ml}$ of $\mathrm{O}_{2} / \mathrm{g}$ of $\mathrm{Hb}$ :

$$
=(\text { Hb satn } / 100) \times \mathrm{Hb} \text { concn }(\mathrm{g} / \mathrm{l}) \times 1.34
$$

Volume of $\mathrm{O}_{2}$ per liter of blood was converted in $\mathrm{mM}$ using the gas volumetric constant $(22.41 \mathrm{~L} / \mathrm{mol})$. For any given $\mathrm{pO}_{2}$, this calculation provides hemoglobin saturation values that are in accordance with the standard oxygen hemoglobin dissociation curve at $\mathrm{pH} 7.4$ and body temperature of $38^{\circ} \mathrm{C}$ (Bartels and Harms, 1959). The saturation curve for cattle is to the right of that for man (Bartels and Harms, 1959).

Carbon dioxide concentration $(\mathrm{m} M)$ was calculated according to Henderson-Hasselbach equation (Oddy et al., 1988):

$$
\begin{aligned}
{\left[\mathrm{CO}_{2}\right]=\left(10^{(\mathrm{pH}-6.12)}\right) } & \left.\times 0.0314 \times \mathrm{pCO}_{2}\right)+(0.0314 \\
& \left.\times \mathrm{pCO}_{2}\right) .
\end{aligned}
$$

Blood flow measured every second using ultrasonic blood flow probes was averaged over six consecutive 2 -h periods. The average values were then used to determine whether there was variation in mammary blood flow over time after milking (see Statistical Analyses section). An average mammary blood flow (MBF) for the entire 12-h period was also estimated according to the Fick principle using a correction factor of $3.5 \%$ for blood-borne proteins secreted directly in milk $(\mathrm{MBF}=(($ milk Phe + Tyr $) \times$ 0.965)/(AV difference Phe + Tyr); Cant et al., 1993). Literature values for milk concentration of phenylalanine and tyrosine were used for calculations (Jensen, 1995). The plasma flow could have been calculated directly with the Fick principle. However, given a $11 \%$ lower arteriovenous (AV) concentration difference for tyrosine measured in plasma compared with whole blood (Table 1), we assumed that the plasma flow would be overestimated this way. Thus, the plasma flow was calculated by multiplying the whole blood flow with its plasma fraction (1-hematocrit). Mammary blood flow measured with the flow probe did not change over time after milking and was very stable across the 12 -h period (Table 2 ). However, the flow probes underestimated mammary blood flow by $30 \%$ on average compared to the value obtained using the Fick principle. The resulting mammary essential amino acid net fluxes, calculated using the blood flow probes, were insufficient to account for their milk output. Thus, a constant mammary blood flow for the whole 12-h period estimated using the Fick principle was considered ade- 
Table 1. Mammary arteriovenous (AV) concentration difference of amino acids in whole blood and plasma. ${ }^{1}$

\begin{tabular}{|c|c|c|c|c|c|c|}
\hline Amino acid & $\begin{array}{l}\text { A-V }(\mu M) \\
\text { Plasma }^{2}\end{array}$ & SEM & $\begin{array}{l}\text { A-V }(\mu M) \\
\text { Whole blood }\end{array}$ & SEM & $\mathrm{F}^{3}$ & $\mathrm{I}^{4}$ \\
\hline Isoleucine & 35.7 & 0.9 & 36.0 & 1.9 & NS & NS \\
\hline Leucine & 54.5 & 1.4 & 54.5 & 2.4 & NS & NS \\
\hline Lysine & 34.1 & 0.3 & 33.6 & 1.3 & NS & NS \\
\hline \multicolumn{7}{|l|}{ Methionine } \\
\hline 2 lac & 11.3 & 0.4 & 11.6 & 0.8 & NS & 0.02 \\
\hline$\geq 3$ lac & 12.2 & 0.4 & 10.8 & 0.4 & & \\
\hline Phenylalanine & 16.3 & 0.4 & 17.0 & 0.6 & NS & NS \\
\hline Threonine & 22.3 & 0.5 & 20.4 & 1.5 & NS & NS \\
\hline Tyrosine & 16.0 & 0.4 & 17.7 & 0.9 & 0.03 & NS \\
\hline
\end{tabular}

${ }^{1}$ Least square means and pooled SEM; $\mathrm{n}=3$ for second-lactation (2 lac) cows and $\mathrm{n}=4$ for third- and fourth-lactation (3 lac) cows.

${ }^{2}$ Plasma AV differences were corrected for hematocrit (see materials and methods section).

${ }^{3}$ Probability of fluid (F) effect; NS = nonsignificant $P>0.10$.

${ }^{4}$ Probability of the interaction (I) between fluid effect (whole blood or plasma) and lactation number (2 lac vs. $\geq 3$ lac).

quate and was used in the calculations of mammary net fluxes. Extraction rate of nutrients was calculated as the arteriovenous concentration difference of a component in whole blood or plasma divided by its respective arterial concentration multiplied by 100 . Whole blood and plasma net fluxes were calculated as the products of net arteriovenous concentration difference of the component in whole blood or plasma and its respective flow measured using the Fick principle. Comparison between whole blood and plasma mammary AV concentration differences of amino acids was carried out on a similar volume basis. Thus, plasma AV concentration differences were multiplied by the plasma fraction in blood (1-hematocrit).

\section{Statistical Analyses}

The temporal variations were statistically analyzed according to a repeated measure design using the follow- ing model of six 2-h periods with two groups of cows (three cows in second lactation and four cows in third and fourth lactation) including degrees of freedom in parentheses:

$$
\begin{gathered}
\mathrm{Y}_{\mathrm{ijkl}}=\mu+\text { lact }_{\mathrm{i}}+\operatorname{cow}\left(\text { lact }_{\mathrm{j}(\mathrm{i})}+\text { time }_{\mathrm{k}}+\text { time }_{\mathrm{k}}\right. \\
\times \text { lact }_{\mathrm{i}}+\mathrm{e}_{(\mathrm{ijkl})}
\end{gathered}
$$

where

$$
\begin{aligned}
& \mathrm{Y}_{\mathrm{ijkl}}=\text { dependent variable, } \\
& \mu=\text { overall mean, } \\
& \text { lact }_{\mathrm{i}}=\text { main effect corresponding to the } i \text {-th } \\
& \text { lactation (1 df), } \\
& \operatorname{cow}(\text { lact })_{j(i)}=\text { effect of individual cow } j \text { nested within } \\
& \text { lactation } i(5 \mathrm{df}) \text {, } \\
& \text { time }_{\mathrm{k}}=\text { main effect corresponding to the } k \text {-th }
\end{aligned}
$$

\begin{tabular}{|c|c|c|c|c|c|c|c|c|c|c|}
\hline & \multicolumn{6}{|c|}{ Average period after the morning milking } & \multirow[b]{2}{*}{ SEM } & \multicolumn{3}{|c|}{$P$-value } \\
\hline & $0-2 \mathrm{~h}$ & $2-4 \mathrm{~h}$ & $4-6 \mathrm{~h}$ & $6-8 \mathrm{~h}$ & $8-10 \mathrm{~h}$ & $10-12 \mathrm{~h}$ & & $\mathrm{PD}^{2}$ & $\mathrm{~T}^{3}$ & $\mathrm{I}^{4}$ \\
\hline Blood flow, ${ }^{5} \mathrm{~L} / \mathrm{h}$ & 452 & 461 & 468 & 467 & 456 & 448 & 10 & & NS & NS \\
\hline Net flux, $\mathrm{mmol} / \mathrm{h}$ & & & & & & & & & & \\
\hline $\mathrm{O}_{2}$ & 621 & 613 & 634 & 615 & 772 & 824 & 77 & 1 & 0.08 & NS \\
\hline $\mathrm{CO}_{2}$ & 1244 & 1520 & 1443 & 1198 & 1387 & 1128 & 120 & 4 & 0.04 & $\mathrm{~N}$ \\
\hline Glucose & 422 & 425 & 417 & 432 & 443 & 428 & 10 & & NS & NS \\
\hline $\mathrm{RQ}\left(\mathrm{CO}_{2} / \mathrm{O}_{2}\right)$ & 2.31 & 2.66 & 2.35 & 2.01 & 1.84 & 1.40 & 0.26 & 1 & 0.02 & NS \\
\hline
\end{tabular}

Table 2. Temporal variation of mammary blood flow, net fluxes of glucose, oxygen, and carbon dioxide production and mammary respiratory quotient (RQ) during a 12-h period following milking. ${ }^{1}$

${ }^{1}$ Least square means and pooled SEM; $n=3$ for second-lactation cows and $n=4$ for third- and fourthlactation cows.

${ }^{2}$ Highest polynomial degree (PD) of significant time effect or its interaction with lactation number (see Materials and Methods section).

${ }^{3}$ Probability of time (T) effect for the polynomial degree given to its left (see Materials and Methods section); NS = nonsignificant $P>0.10$.

${ }^{4}$ Probability of the interaction (I) between time effect (polynomial degree to its left) and lactation number.

${ }^{5}$ Udder blood flow measured using an ultrasonic flow probe (half udder measurement multiplied by two). Net flux of nutrients were calculated for each cow using averaged blood flow for the whole period estimated according to the Fick principle (see the Results and Discussion section). 


$$
\begin{aligned}
& \text { time }(5 \mathrm{df}), \\
\text { time }_{\mathrm{k}} \times \text { lact }_{\mathrm{i}}= & \text { interaction effect between the } k \text {-th } \\
& \text { time and the } i \text {-th lactation }(5 \mathrm{df}), \\
\mathrm{e}_{(\mathrm{ijkl})=} & \text { residual error associated with each } \\
& \text { ijkl observation }(25 \mathrm{df}) .
\end{aligned}
$$

Six periods of $2 \mathrm{~h}$ were compared in the statistical model given that the analysis as repeated measures requires a smaller number of periods than the number of experimental units used in the study (Milliken and Johnson, 1984). Statistics were performed using the GLM procedure of SAS (1985). This statistical design allowed us to control the variation in the mammary arteriovenous measurements due to a nonmammary venous backflux into the mammary vein measured previously in the thirdand fourth-lactation cows used in the present study (Thivierge et al., 2000). Cow nested within lactation was used as the error term for determination of lactation number effect. Type III sum of squares was interpreted. Least square means are given in tables with pooled standard error of the mean. Highest polynomial degree of significant time effect or its interaction with lactation number is presented according to principles of nonlinear regression (Steel and Torrie, 1960), and $P \leq 0.05$ was considered significant and $0.05<P \leq 0.10$ was considered as a tendency.

Statistical comparison between whole blood and plasma (fluid in the model) mammary AV concentration difference of amino acids studied was performed as a split-split-plot design using the GLM procedures of SAS (1985). The model used was as follows including degrees of freedom in parentheses:

$$
\begin{gathered}
\mathrm{Y}_{\mathrm{ijkl}}=\mu+\text { lact }_{\mathrm{i}}+\operatorname{cow}\left(\text { lact }_{\mathrm{j}(\mathrm{i})}+\text { time }_{\mathrm{k}}+\right.\text { time } \\
\times \text { lact }_{\mathrm{ki}}+\text { time } \times \text { cow }(\text { lact })_{\mathrm{kj}(\mathrm{i})}+\text { fluid }_{1}+\text { fluid } \\
\times \text { lact }_{\mathrm{li}}+\text { fluid } \times \text { time }_{\mathrm{lk}}+\text { fluid } \times \text { time } \times \text { lact }_{\mathrm{kki}}+\mathrm{e}_{\mathrm{ijkl}}
\end{gathered}
$$

where

$$
\begin{aligned}
\mathrm{Y}_{\mathrm{ijkl}}= & \text { dependent variable, } \\
\mu= & \text { overall mean effect, } \\
\text { lact }_{\mathrm{i}}= & \text { main effect corresponding to the } \\
& i \text {-th lactation }(1 \mathrm{df}), \\
\operatorname{cow}\left(\text { lact }_{\mathrm{j}(\mathrm{i})}=\right. & \text { effect of individual cow } j \text { nested } \\
& \text { within lactation } i(5 \mathrm{df}), \\
\text { time }_{\mathrm{k}} \mathrm{k}= & \text { main effect corresponding to the } \\
& k \text {-th time }(5 \mathrm{df}), \\
\text { time } \times \text { lact }_{\mathrm{ki}}= & \text { interaction effect between the } k \text { - } \\
& \text { th time and the } i \text {-th lactation }(5 \\
& \text { df), } \\
\text { time } \times \operatorname{cow}(\text { lact })_{\mathrm{kj}(\mathrm{i})}= & \text { interaction between the } k \text {-th } \\
& \text { time and cow } j \text { nested in lacta- } \\
& \text { tion } i(25 \mathrm{df}), \\
\text { fluid }_{1}= & \text { main effect corresponding to the }
\end{aligned}
$$

$$
\begin{aligned}
& l \text {-th fluid }(1 \mathrm{df}), \\
\text { fluid } \times \text { lact }_{\mathrm{li}}= & \text { interaction between fluid } l \text { and } \\
& \text { lact } i(1 \mathrm{df}), \\
\text { fluid } \times \text { time }_{\mathrm{lk}}= & \text { interaction between fluid } l \text { and } \\
& \text { time } k(5 \mathrm{df}), \\
\text { fluid } \times \text { time } \times \text { lact }_{\mathrm{lki}}= & \text { interaction between fluid } l \text {, time } \\
& k \text { and lact } i(5 \mathrm{df}), \\
\mathrm{e}_{(\mathrm{ijkl})}= & \text { residual error associated with } \\
& \text { each ijkl observation, }(30 \mathrm{df}) .
\end{aligned}
$$

Cow nested within lactation was used as the error term for determination of lactation number effect. The term time $\times \operatorname{cow}$ (lact) was used as the error term for determination of time and time $\times$ lact effect. Type III sum of square was interpreted. Least square means are given in tables with pooled standard error of the mean.

\section{RESULTS AND DISCUSSION}

\section{DMI and Milk Composition}

On the day of blood sampling and during the preceding $3 \mathrm{~d}$, no orts were recorded and daily DMI averaged 20.2 $\mathrm{kg}$ (SEM 1.5) in second-lactation cows and $19.8 \mathrm{~kg}$ (SEM 1.4) in cows in third or fourth lactation. Daily milk yield averaged $29.2 \mathrm{~kg}$ (SEM 3.7) versus 36.1 (SEM 1.2) $\mathrm{kg}$ in cows in second versus in third and higher lactations, respectively. Milk CP content and yield averaged 3.28\% (SEM 0.06) and $955 \mathrm{~g}$ daily (SEM 103), respectively, in second-lactation cows and 3.24\% (SEM 0.12) and $1166 \mathrm{~g}$ daily (SEM 28), respectively, in third- or fourth-lactation cows.

\section{Arterial Concentration of $\mathrm{O}_{2}, \mathrm{CO}_{2}$, and Glucose}

Blood $\mathrm{pH}$ remained stable over the 12 -h period, averaging 7.445 (Table 3; SEM 0.004) and arterial hemoglobin was $97.8 \%$ saturated with oxygen constantly over time, which indicates that the affinity of hemoglobin for oxygen did not vary across the period studied. Arterial concentration of oxygen and $\mathrm{CO}_{2}$ were also stable over time. This is in accordance with arterial $\mathrm{O}_{2}, \mathrm{CO}_{2}$ and $\mathrm{pH}$ homeostasis, indicating that alveolar ventilation is adjusted to whole body metabolism in order to maintain a constant arterial $\mathrm{O}_{2}$ and $\mathrm{CO}_{2}$ concentration as well as blood $\mathrm{pH}$ (Guyton and Hall, 1996b).

Arterial plasma glucose concentration tended to vary according to a third polynomial degree over time after milking ( $P=0.08$; Table 3$)$. This appears to have limited biological meaning as the greatest change in arterial glucose concentration only reached $2.3 \%$, which is within the physiological range of glucose concentration in cattle (Dubreuil and Lapierre, 1997). 
Table 3. Temporal variation of blood $\mathrm{pH}$, arterial and mammary venous hemoglobin saturation with oxygen, and arterial concentration of oxygen, carbon dioxide, and glucose during a 12 -h period following milking. ${ }^{1}$

\begin{tabular}{|c|c|c|c|c|c|c|c|c|c|c|}
\hline & \multicolumn{6}{|c|}{ Average period after the morning milking } & \multirow[b]{2}{*}{ SEM } & \multicolumn{3}{|c|}{$P$-value } \\
\hline & $0-2 \mathrm{~h}$ & $2-4 \mathrm{~h}$ & $4-6 \mathrm{~h}$ & $6-8 \mathrm{~h}$ & $8-10 \mathrm{~h}$ & $10-12 \mathrm{~h}$ & & $\mathrm{PD}^{2}$ & $\mathrm{~T}^{3}$ & $\mathrm{I}^{4}$ \\
\hline Blood pH & 7.449 & 7.444 & 7.443 & 7.447 & 7.444 & 7.442 & 0.004 & & NS & NS \\
\hline \multicolumn{11}{|c|}{ Hemoglobin saturation with oxygen, $\%$} \\
\hline Arterial blood ${ }^{5}$ & 97.8 & 97.8 & 97.8 & 97.8 & 97.8 & 97.8 & 0.0 & & NS & NS \\
\hline Venous blood ${ }^{6}$ & 81.4 & 80.8 & 80.3 & 81.2 & 77.6 & 77.7 & 1.2 & 1 & 0.06 & NS \\
\hline \multicolumn{11}{|c|}{ Arterial concentration, $\mathrm{m} M$} \\
\hline $\mathrm{O}_{2}$ & 5.26 & 5.22 & 5.29 & 5.23 & 5.24 & 5.24 & 0.05 & & NS & NS \\
\hline $\mathrm{CO}_{2}$ & 27.2 & 26.9 & 26.6 & 26.9 & 26.5 & 26.6 & 0.2 & & NS & NS \\
\hline Glucose & 3.41 & 3.40 & 3.39 & 3.37 & 3.33 & 3.38 & 0.02 & 3 & 0.08 & NS \\
\hline
\end{tabular}

${ }^{1}$ Least square means and pooled SEM; $n=3$ for second-lactation cows and $n=4$ for third- and fourthlactation cows.

${ }^{2}$ Highest polynomial degree (PD) of significant time effect or its interaction with lactation number (see Materials and Methods section).

${ }^{3}$ Probability of time (T) effect for the polynomial degree given to its left (see Materials and Methods section); NS $=$ nonsignificant $P>0.10$.

${ }^{4}$ Probability of the interaction (I) between time effect (polynomial degree to its left) and the number of lactation.

${ }^{5}$ Average arterial $\mathrm{pO}_{2} 108.5 \mathrm{~mm}$ of $\mathrm{Hg}$ (SEM 2.6).

${ }^{6}$ Average mammary venous $\mathrm{pO}_{2} 38.8 \mathrm{~mm}$ of $\mathrm{Hg}$ (SEM 0.6).

\section{Concentration of Amino Acids}

The arterial blood concentration of isoleucine, phenylalanine, and threonine did not change over the 12-h period, while leucine, methionine, and tyrosine exhibited a significant interaction (Figure $1 ; P \leq 0.05$ ) between time after milking and lactation number. Lysine tended $(P=$ $0.08)$ to exhibit this same interaction. Given that the cows were fed every $2 \mathrm{~h}$ and that each meal was completely eaten before the following one, it appears that these variations would originate from circadian rhythms. The amino acid patterns in the mammary venous blood appear to follow trends similar to the arterial patterns, except for leucine (Figure 2). These temporal variations of amino acid concentrations in the mammary venous blood did not reach significance, in contrast to the arterial blood, with the exception of threonine. The fact that the mammary venous concentrations of amino acids were 15 to $33 \%$ lower than their respective arterial concentrations may explain this discrepancy.

A significant interaction $(P \leq 0.05)$ between time after milking and lactation number was observed for arterial plasma isoleucine, leucine, lysine, threonine, and tyrosine concentrations (Figure 3 ). Methionine and phenylalanine tended $(P \leq 0.10)$ to exhibit this interaction. As observed for whole blood, mammary venous plasma concentrations of amino acids followed a similar trend over time as their arterial concentrations (Figure 4). Once again, given that their concentration in mammary venous plasma represented only 33 to $60 \%$ of their respective arterial plasma concentrations (Table 4), the resulting variations in mammary venous plasma were not significant with the exception of threonine and tyrosine.
Analogous temporal patterns between arterial and mammary venous plasma amino acid concentration have also been observed by Mackle et al. (2000a). As in the present study, their experiment was not specifically planned to study amino acid circadian rhythms; this would have required repeated measurements on successive days to corroborate the observations. To our knowledge, circadian rhythms in concentrations and fluxes of amino acids have not been studied in lactating dairy cows. A variety of factors can influence the level of individual amino acids in blood given that their peripheral concentration is the balance between input and removal. Fluctuations in amino acid concentration have been associated with nondietary signals such as the time of the day in humans (Tsai and Huang, 1999) and sex in rats (Kobayashi et al., 1997). The liver has a great influence on peripheral appearance of amino acids. In rats, the liver exhibits circadian rhythms in the incorporation of amino acids into proteins according to the time of day (Stahr et al., 1980). Overall, the rhythms over time of the amino acids in blood and plasma in the present study do not seem to be linked to feed intake, as also seen in sheep (Purser et al., 1966) and in humans (Wurtman et al., 1967l, 1968). The interaction between time after milking and lactation number observed in arterial blood and plasma concentration of many amino acids may be linked to physiological status, as cows in third and fourth lactation were in an earlier stage of lactation (93 DIM) than younger cows (217 DIM).

\section{Mammary Arterial Blood Flow}

Mammary gland arterial blood flow, which was continuously recorded using an ultrasonic flow probe, exhibited 

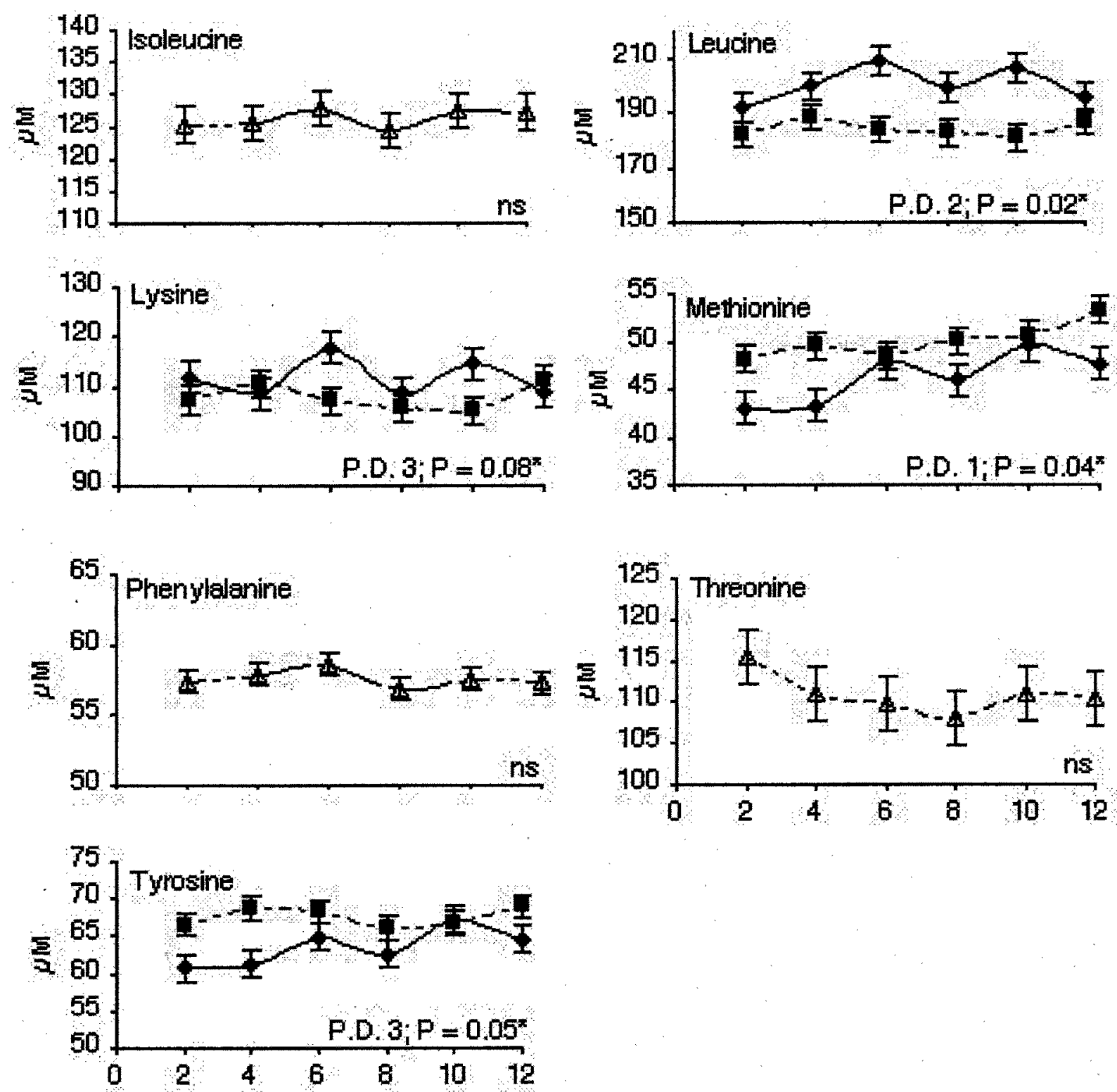

Figure 1. Temporal variation of whole blood arterial concentration of amino acids during a 12-h period following milking; - $-\mathbf{- s e c o n d -}$ and $\cdots \cdot \cdots \cdot \cdot$ third- and fourth-lactation cows; $-\cdot \triangle+\cdot \cdot$ average concentration for all cows. Abbreviations: P.D. = polynomial degree of the temporal variation or the interaction (indicated by *) between the time effect and lactation number; ns $=$ nonsignificant $P>0.10$.

no temporal variation as the udder gradually filled with milk over the 12-h period following the morning milking (Table 2). Many factors appear to be involved in local blood flow regulation, such as the secretion of local vasodilator agents (Prosser et al., 1996). Blood flow may also be regulated by the tissue oxygen requirements. When hemoglobin saturation with oxygen falls by about $25 \%$ at the arterial capillary level, arterial blood supply adjusts to maintain a constant supply of oxygen to the tissue (Guyton and Hall, 1996a). In the present study, the arterial saturation of hemoglobin with oxygen re- mained at $97.8 \%$, while the venous saturation of hemoglobin with oxygen tended to fall linearly with time $(P=0.06)$ from 81.4 to $77.7 \%$ (Table 3). This decrease in venous saturation of hemoglobin with $\mathrm{O}_{2}$ did not exceed the proposed limit of a $25 \%$ decrease in hemoglobin saturation percentage (Guyton and Hall, 1996a). Therefore, an increase in mammary blood flow was not required, and the present measurements show that, indeed, mammary blood flow was stable over the 12 -h period.

A linear regression was performed between the average of mammary blood flow measured with the flow 

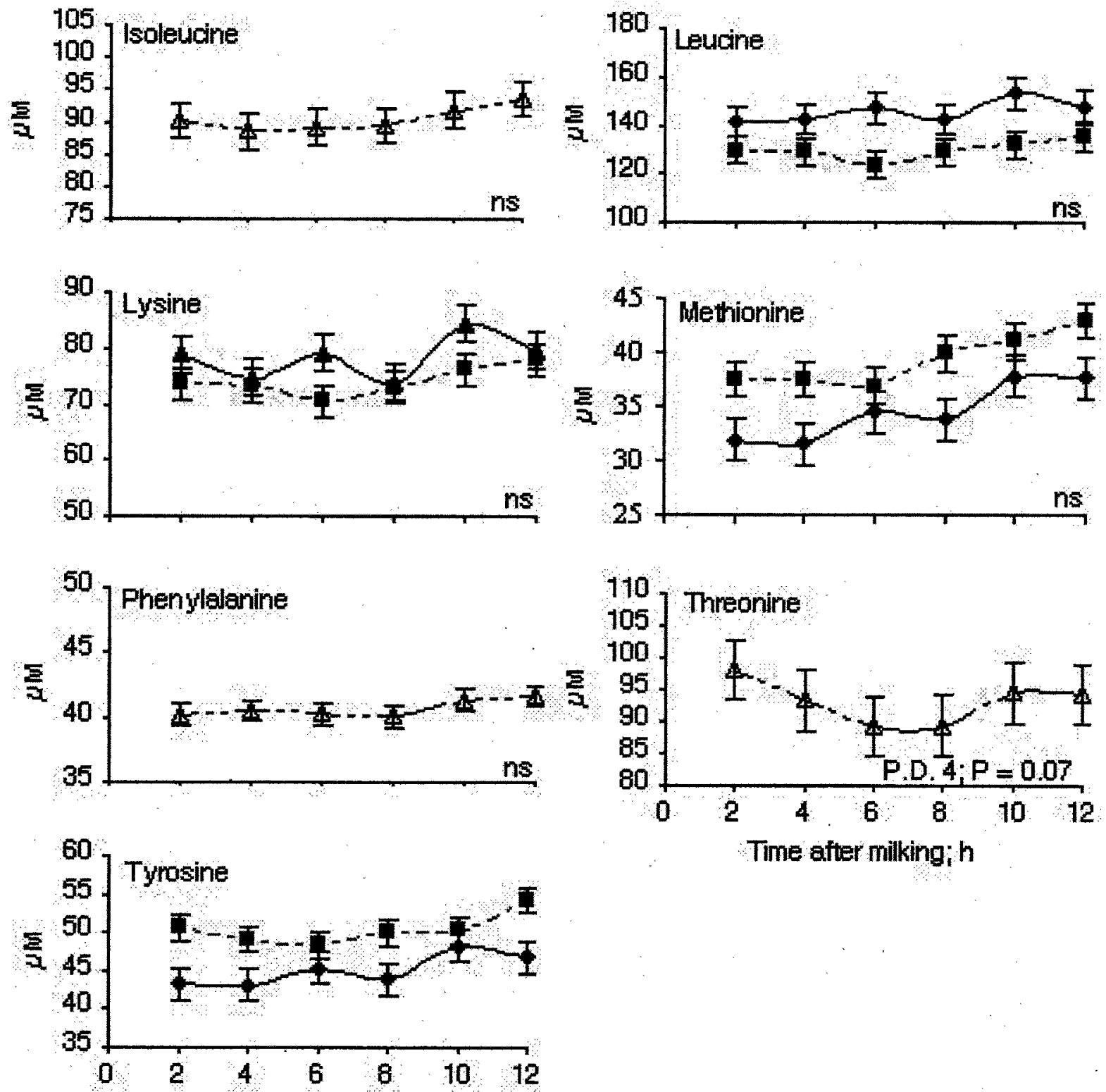

Figure 2. Temporal variation of whole blood mammary venous concentration of amino acids during a 12-h period following milking; - - second- and … $\cdots \cdot$ third- and fourth-lactation cows; $-\cdot \triangle-\cdot \cdot$ average concentration for all cows. Abbreviations: P.D. = polynomial degree of the temporal variation or the interaction (indicated by $*$ ) between the time effect and lactation number; ns $=$ nonsignificant $P>0.10$.

probes and its estimate calculated according to the Fick principle. The relationship between the two variables was strong $\left[\right.$ Fick $(\mathrm{L} / \mathrm{h})=2.4$ Probe $(\mathrm{L} / \mathrm{h})-463 ; \mathrm{n}=7 ; \mathrm{r}^{2}$ $=0.96 ; P<0.01])$; however, the flow probe underestimated mammary blood flow calculated by the Fick principle by $30 \%$. Similar underestimations (15 to $28 \%$ ) were also reported when blood flows measured with ultrasonic flow probes were compared to values estimated with the dye dilution technique (Bequette et al., 1999; Mabjeesh et al., 2000). The resulting mammary essential amino acid net fluxes, calculated using the blood flow probe, were insufficient to account for their milk output. Therefore, mammary blood flow estimated according to the Fick principle using the sum of phenylalanine and tyrosine as markers (Cant et al., 1993) was preferred to the values obtained with the probes. Phenylalanine is not oxidized within the mammary gland (Bequette et al., 1999; Verbeke et al., 1972) and is transferred quantitatively from 

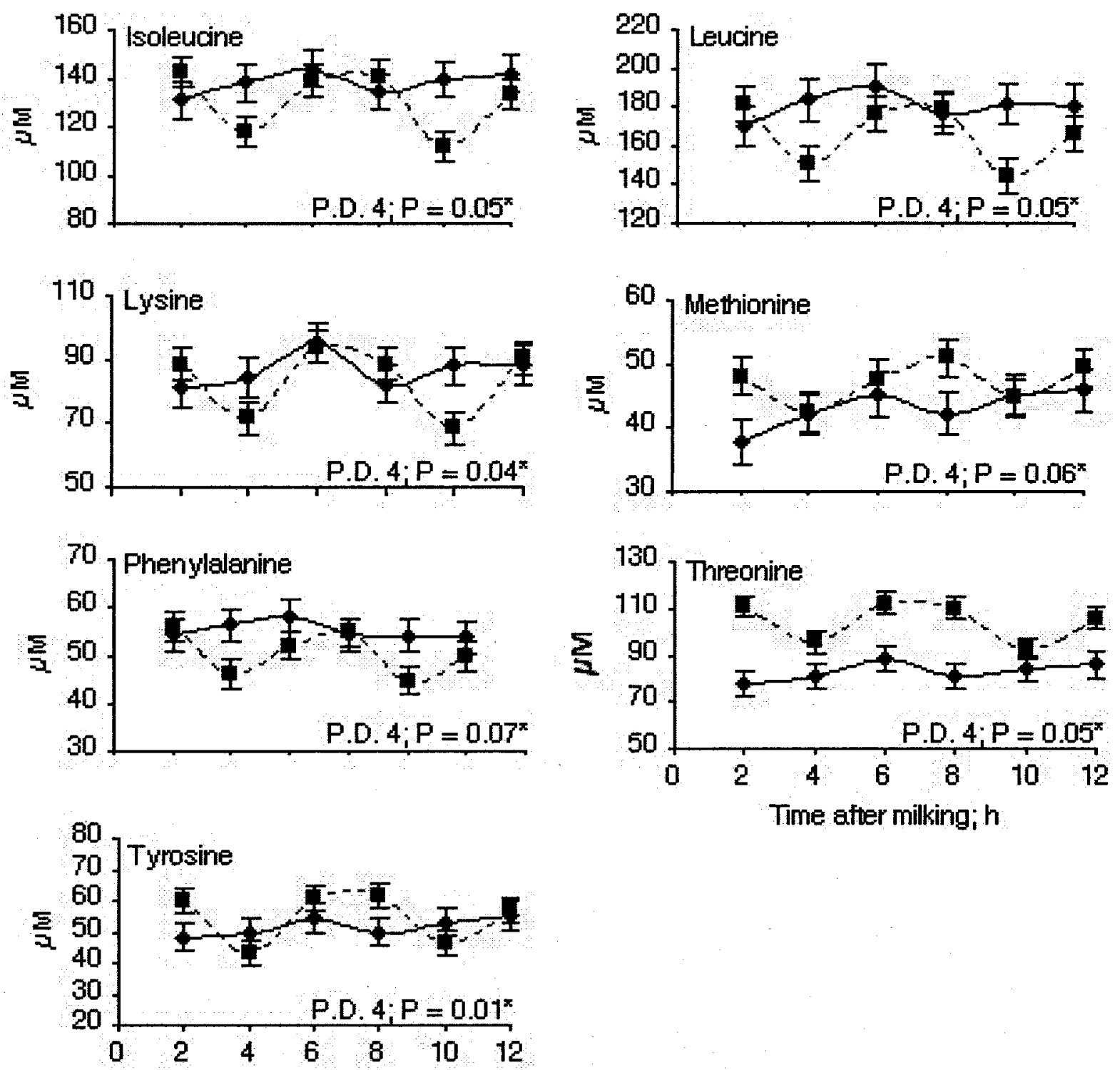

Figure 3. Temporal variation of arterial plasma concentration of amino acids during a 12-h period following milking; - - - second- and $\cdots \cdot \cdots \cdot$ third- and fourth-lactation cows; $-\cdot \triangle-\cdot \cdot$ average concentration for all cows. Abbreviations: P.D. = polynomial degree of the temporal variation or the interaction (indicated by $*$ ) between the time effect and lactation number; ns $=$ nonsignificant $P>0.10$.

blood to milk (Mepham, 1982) and is thus considered to be a reliable marker. Tyrosine was measured concomitantly as suggested by Cant et al. (1993), given that mammary phenylalanine hydroxylation to tyrosine represents 3 to $5 \%$ of mammary phenylalanine flux (Bequette et al., 1999). Tyrosine is also transferred quantitatively from blood to milk (Mepham, 1982). Blood flow estimated using the Fick principle was $646 \mathrm{~L} / \mathrm{h}$ (SEM 72 ) in second-lactation cows and $840 \mathrm{~L} / \mathrm{h}$ (SEM 72) in third- or fourth-lactation cows. Plasma flow calculated from whole blood flow corrected for hematocrit was 465
L/h (SEM 58) in second-lactation cows and $613 \mathrm{l} / \mathrm{h}$ (SEM 51) in cows in third or fourth lactation, which were producing more milk.

\section{Mammary Nutrient Extraction Rate}

As blood flow did not change over time (Table 2), arteriovenous concentration differences of nutrients are not presented here, as they give similar results as net flux measurements. Mammary oxygen extraction rate tended to increase linearly $(P=0.06$; Table 4$)$ over time after 

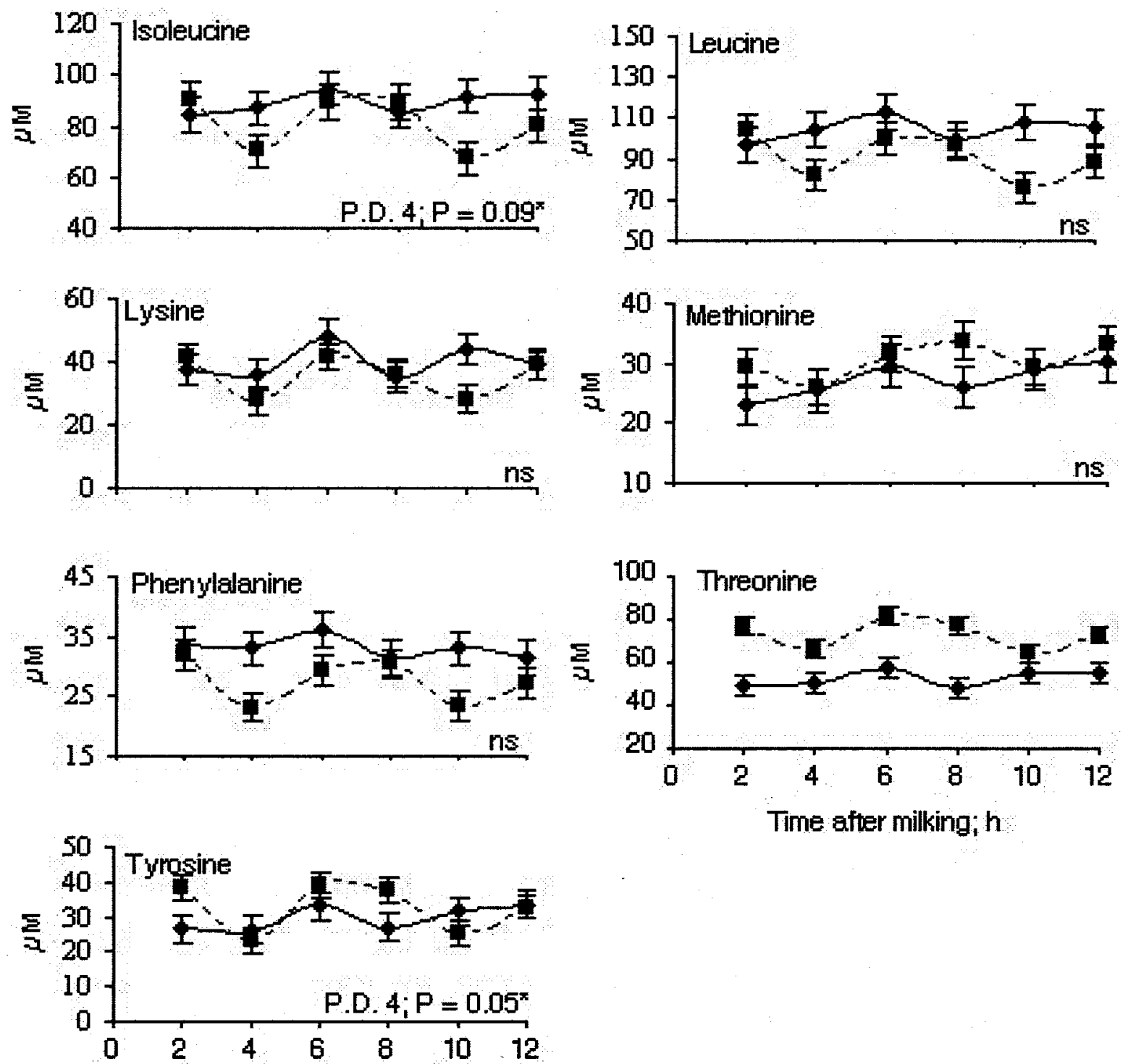

Figure 4. Temporal variation of mammary venous plasma concentration of amino acids during a 12-h period following milking; second- and $\cdots \cdot \cdots \cdot \cdot$ third- and fourth-lactation cows; $-\cdot \triangle-\cdot \cdot$ average concentration for all cows. Abbreviations: P.D. $=$ polynomial degree of the temporal variation or the interaction (indicated by $*$ ) between the time effect and lactation number; ns $=$ nonsignificant $P>0.10$.

milking from 15.9 to $21.4 \%$, while mammary glucose extraction remained steady and averaged $24 \%$ of arterial concentration. The constant arterial concentration of oxygen over the 12-h period (Table 3) in conjunction with the increased extraction rate suggests that the mammary requirements for oxidation tended to increase with time after milking. An increase in oxygen requirements is also supported by the fact that hemoglobin saturation with $\mathrm{O}_{2}$ remained constant in arterial blood but declined in venous blood. Whole blood mammary leucine extraction rate tended to exhibit a quadratic relationship over time $(P=0.08)$, with a maximum rate 4 to $6 \mathrm{~h}$ after the morning milking and a minimum rate over the last $2 \mathrm{~h}$ of the sampling period (Table 4). Lysine tended to exhibit a cubic relationship with time $(P=0.06)$. Similar to leucine, there was a maximum extraction rate 4 to $6 \mathrm{~h}$ after the morning milking and a minimum extraction rate over the last $4 \mathrm{~h}$ of the period. Mammary whole blood extraction rate for methionine $(P=0.06)$ and phenylalanine $(P=$ $0.10)$ tended to decrease linearly with time. The temporal variations in extraction rates of tyrosine, isoleucine, and threonine were not significant, but they numerically follow a similar pattern as the other amino acids. Overall, mammary extraction of amino acids in whole blood reached a maximum rate from the 2 - to 4 -h to the 4 - to 6 -h periods after the morning milking and decreased to 
Table 4. Temporal variation of mammary extraction rate (\%) of oxygen, glucose, and seven amino acids in whole blood and plasma during a 12 -h period following milking. ${ }^{1}$

\begin{tabular}{|c|c|c|c|c|c|c|c|c|c|c|}
\hline & \multicolumn{6}{|c|}{ Average period after the morning milking } & \multirow[b]{2}{*}{ SEM } & \multicolumn{3}{|c|}{$P$-value } \\
\hline & $0-2 \mathrm{~h}$ & $2-4 \mathrm{~h}$ & $4-6 \mathrm{~h}$ & $6-8 \mathrm{~h}$ & $8-10 \mathrm{~h}$ & $10-12 \mathrm{~h}$ & & $\mathrm{PD}^{2}$ & $\mathrm{~T}^{3}$ & $\mathrm{I}^{4}$ \\
\hline Glucose & 23.6 & 23.9 & 23.6 & 24.1 & 24.8 & 24.0 & 0.5 & & NS & NS \\
\hline $\mathrm{O}_{2}$ & 15.9 & 15.9 & 16.8 & 15.8 & 20.3 & 21.4 & 1.8 & 1 & 0.06 & NS \\
\hline \multicolumn{11}{|c|}{ Whole blood amino acid } \\
\hline Isoleucine & 27.8 & 29.6 & 30.3 & 28.3 & 28.2 & 26.7 & 1.2 & & NS & NS \\
\hline Leucine & 27.4 & 30.1 & 31.1 & 28.8 & 26.3 & 25.8 & 1.5 & 2 & 0.08 & NS \\
\hline Lysine & 30.2 & 32.7 & 33.3 & 31.3 & 26.8 & 27.7 & 1.7 & 3 & 0.06 & NS \\
\hline Methionine & 24.3 & 26.0 & 25.9 & 24.0 & 21.9 & 20.9 & 1.2 & 1 & 0.06 & NS \\
\hline Phenylalanine & 30.6 & 30.8 & 32.0 & 30.0 & 28.7 & 27.4 & 1.2 & 1 & 0.10 & NS \\
\hline Threonine & 16.9 & 17.7 & 19.3 & 18.4 & 15.5 & 15.4 & 2 & & NS & NS \\
\hline Tyrosine & 26.2 & 28.7 & 29.1 & 26.7 & 26.4 & 24.1 & 1.6 & & NS & NS \\
\hline \multicolumn{11}{|c|}{ Plasma amino acid } \\
\hline Isoleucine & 36.1 & 38.9 & 35.5 & 36.8 & 37.9 & 37.7 & 1.5 & & NS & NS \\
\hline Leucine & 43.3 & 44.6 & 42.8 & 45.0 & 44.8 & 44.8 & 2.0 & & NS & NS \\
\hline Lysine & 53.8 & 60.0 & 54.6 & 58.9 & 55.8 & 56.1 & 2.8 & 5 & 0.03 & NS \\
\hline Methionine & 39.5 & 40.4 & 35.5 & 36.7 & 38.3 & 35.5 & 2.0 & & NS & NS \\
\hline Phenylalanine & 42.2 & 47.0 & 42.2 & 43.8 & 44.4 & 44.4 & 1.6 & & NS & NS \\
\hline Threonine & 35.3 & 37.2 & 33.1 & 37.5 & 35.6 & 34.7 & 1.5 & 5 & 0.02 & NS \\
\hline Tyrosine & 40.5 & 47.6 & 38.1 & 42.3 & 43.9 & 41.3 & 2.3 & 5 & 0.03 & NS \\
\hline
\end{tabular}

${ }^{1}$ Least square means and pooled SEM; $n=3$ for second-lactation cows and $n=4$ for third- and fourthlactation cows.

${ }^{2}$ Highest polynomial degree (PD) of significant time effect or its interaction with lactation number (see Materials and Methods section).

${ }^{3}$ Probability of time (T) effect for the polynomial degree given to its left (see Materials and Methods section); NS = nonsignificant $P>0.10$.

${ }^{4}$ Probability of the interaction (I) between time effect (polynomial degree to its left) and lactation number.

the lowest rate from the 8 - to 10 -h to the 10 - to 12 -h periods after milking.

Plasma extraction rate of isoleucine, leucine, methionine, and phenylalanine were not significantly affected by time after milking and averaged $37,44,37$, and $44 \%$, respectively (Table 4). Lysine, threonine, and tyrosine extraction rate exhibited a quintic rhythm $(P<0.05)$ over time after milking, which varied from 38 to $48 \%$ for tyrosine, 54 to $60 \%$ for lysine and 33 to $38 \%$ for threonine.

\section{Mammary Nutrient Net Fluxes}

The linear increase in mammary oxygen extraction rate over time after milking (Table 4) resulted in a $33 \%$ increase in mammary oxygen net flux over the 12 -h pe$\operatorname{riod}(P=0.08$; Table 2$)$. This increased mammary oxygen net flux over time suggests that requirements for oxidation tended to increase with time after milking. On the other hand, carbon dioxide produced by the mammary gland exhibited a quartic pattern $(P=0.04)$ over time after milking. There was a $19 \%$ increase of $\mathrm{CO}_{2}$ production from the 0 - to 2 -h period to the 2 - to 6 -h period after the morning milking, followed by a $19 \%$ decrease during the next 2-h period, and then a return close to the initial production rate. From the 6- to 8-h period to the 8- to 10-h period after milking, $\mathrm{CO}_{2}$ produced by the udder increased by $16 \%$, and from the 8 - to 10 -h to 10 - to 12 - $\mathrm{h}$ period after milking, it declined by $19 \%$. The resulting respiratory quotients decreased linearly $(P=0.02$; Table 2 ) as the udder gradually filled with milk over the 12 -h period. Starting at 2.31 during the 0 - to 2 -h period after the morning milking, it was reduced to 1.40 at the end of the 12-h period. Mammary glucose net flux remained stable over the period studied and averaged $428 \mathrm{mmol} / \mathrm{h}$.

Respiratory quotients above one are characteristic of the conversion of nutrients rich in oxygen such as glucose or acetate to products relatively poor in oxygen such as fatty acids (Elia and Livesey, 1987). Lipid synthesis cannot proceed without glucose or acetate oxidation, either for their conversion into lipids or for providing energy and reducing equivalents needed for lipogenesis (Baldwin, 1968; Elia and Livesey, 1987). The elevated respiratory quotients measured over the first $6 \mathrm{~h}$ after milking suggest that extensive fatty acid synthesis occurred during that period. This would be consistent with de novo synthesis of short- and medium-chain fatty acids and about half of the palmitic acid occurring within the mammary gland (Palmquist and Jenkins, 1980).

The last $6 \mathrm{~h}$ of the period was characterized by a continued reduction in respiratory quotients from 2.01 to 1.40 and an increase in mammary oxygen uptake from 615 to $824 \mathrm{mmol} / \mathrm{h}$. This suggests that the mammary metabolism shifted towards more oxidative processes and a lowered lipid synthesis during these last $6 \mathrm{~h}$. 
Table 5. Temporal variation of mammary net flux $(\mathrm{mmol} / \mathrm{h})$ of amino acids in whole blood and plasma during a 12-h period following milking. ${ }^{1,2}$

\begin{tabular}{|c|c|c|c|c|c|c|c|c|c|c|}
\hline & \multicolumn{6}{|c|}{ Average period after the morning milking } & \multirow[b]{2}{*}{ SEM } & \multicolumn{3}{|c|}{$P$-value } \\
\hline & $0-2 \mathrm{~h}$ & $2-4 \mathrm{~h}$ & $4-6 \mathrm{~h}$ & $6-8 \mathrm{~h}$ & $8-10 \mathrm{~h}$ & $10-12 \mathrm{~h}$ & & $\mathrm{PD}^{3}$ & $\mathrm{~T}^{4}$ & $\mathrm{I}^{5}$ \\
\hline \multicolumn{11}{|c|}{ Whole blood } \\
\hline Ile & 25.4 & 27.3 & 27.5 & 25.4 & 26.0 & 24.2 & 1.2 & & NS & NS \\
\hline Leu & 37.4 & 42.5 & 43.1 & 39.5 & 36.4 & 35.2 & 2.1 & 2 & 0.04 & NS \\
\hline Lys & 23.8 & 26.0 & 26.5 & 24.1 & 21.1 & 22.3 & 1.5 & 3 & 0.04 & NS \\
\hline \multicolumn{11}{|l|}{ Met } \\
\hline 2 lac & 6.9 & 7.3 & 8.2 & 7.6 & 7.3 & 5.9 & 0.7 & 3 & NS & 0.06 \\
\hline$\geq 3$ lac & 8.9 & 10.1 & 9.4 & 8.5 & 8.1 & 8.5 & 0.6 & & & \\
\hline Phe & 12.5 & 12.7 & 13.0 & 12.1 & 11.7 & 11.2 & 0.5 & 1 & 0.08 & NS \\
\hline Thr & 13.1 & 13.3 & 14.9 & 13.6 & 11.8 & 11.8 & 1.6 & & NS & NS \\
\hline Tyr & 11.9 & 13.5 & 13.6 & 12.2 & 12.6 & 11.3 & 0.8 & & NS & NS \\
\hline Sum & 132 & 144 & 147 & 135 & 127 & 123 & 7 & 3 & 0.09 & NS \\
\hline \multicolumn{11}{|l|}{ Plasma } \\
\hline \multicolumn{11}{|l|}{ Ile } \\
\hline 2 lac & 20.7 & 22.1 & 22.5 & 21.6 & 21.5 & 22.0 & 1.8 & 2 & NS & 0.08 \\
\hline$\geq 3$ lac & 30.9 & 28.7 & 30.0 & 31.3 & 27.6 & 32.2 & 1.6 & & & \\
\hline Leu & 39.1 & 37.7 & 41.2 & 42.0 & 37.9 & 40.4 & 2.2 & & NS & NS \\
\hline \multicolumn{11}{|l|}{ Lys } \\
\hline 2 lac & 19.5 & 21.4 & 21.4 & 20.9 & 20.2 & 22.5 & 2.5 & 4 & 0.06 & 0.09 \\
\hline$\geq 3$ lac & 27.5 & 26.4 & 32.3 & 31.9 & 24.9 & 30.9 & 2.2 & & & \\
\hline Met & 8.9 & 8.5 & 8.4 & 8.7 & 8.3 & 8.5 & 0.4 & & NS & NS \\
\hline \multicolumn{11}{|l|}{ Phe } \\
\hline 2 lac & 9.2 & 10.4 & 10.3 & 10.2 & 9.5 & 10.0 & 0.7 & 3 & NS & 0.05 \\
\hline$\geq 3$ lac & 14.4 & 13.8 & 13.7 & 14.8 & 13.1 & 13.7 & 0.6 & & & \\
\hline \multicolumn{11}{|l|}{ Thr } \\
\hline 2 lac & 13.0 & 13.6 & 13.9 & 14.6 & 13.0 & 13.8 & 1.1 & 2 & NS & 0.04 \\
\hline$\geq 3$ lac & 20.1 & 17.8 & 18.6 & 19.8 & 17.4 & 20.2 & 1.0 & & & \\
\hline Tyr & 11.3 & 11.2 & 11.5 & 12.3 & 11.3 & 12.3 & 0.7 & & NS & NS \\
\hline Sum & 137 & 134 & 142 & 146 & 131 & 143 & 6 & & NS & NS \\
\hline
\end{tabular}

${ }^{1}$ Least square means and pooled SEM; $\mathrm{n}=3$ for second-lactation cows (2 lac) and $\mathrm{n}=4$ for third- and fourth-lactation cows $(\geq 3$ lac). Values reported separately when the interaction at least tended to be significant $(P \leq 0.10) ; \mathrm{NS}=$ nonsignificant $P>0.10$.

${ }^{2} \mathrm{Net}$ flux of nutrients were calculated for each cow using averaged blood flow for the whole period estimated according to the Fick principle (see the Results and Discussion section).

${ }^{3}$ Highest polynomial degree (PD) of significant time effect or its interaction with lactation number (see Materials and Methods section).

${ }^{4}$ Probability of time (T) effect for the polynomial degree given to its left (see Materials and Methods section).

${ }^{5}$ Probability of the interaction (I) between time effect (polynomial degree to its left) and lactation number; data are presented for each group when the interaction is significant.

Whole blood mammary leucine net flux varied quadratically with time $(P=0.04)$, with a $14 \%$ increase in the 2 to 6 -h period after milking compared with the 0 - to 2 -h period, followed by a decrease of $18 \%$ over the next $6-\mathrm{h}$ period (Table 5). Lysine net flux followed a cubic pattern, starting at $23.8 \mathrm{mmol} / \mathrm{h}$. It increased by $10 \%$ in the 2 - to 6 -h period after milking and then decreased by $17 \%$ at the 10- to 12-h period after milking. Mammary methionine net flux in whole blood tended to exhibit a cubic relationship with time, which differed between lactation numbers $(P=0.06)$. In second-lactation cows, a $13 \%$ increase was observed from the 0 - to 2 -h period to the averaged 2- to 6 -h period after milking and then a $24 \%$ decline was observed over the remaining $6 \mathrm{~h}$. Methionine net flux in whole blood in older cows increased by $18 \%$ from the 0 -to 2 -h period to the averaged 2- to 6 -h period after milking and decreased by $19 \%$ over the following 6 h. Phenylalanine net flux in whole blood tended to decrease linearly $(P=0.08$; Table 5$)$ over the 12 -h period. Isoleucine, threonine, and tyrosine net fluxes in whole blood did not vary significantly over time after milking, averaging $26.0,13.1$, and $12.5 \mathrm{mmol} / \mathrm{h}$, respectively. Although these three amino acids did not exhibit a significant temporal pattern over the 12 -h period, their numerical values followed the same trend observed for the other amino acids. The individual rhythms of amino acid net uptakes over time after milking may vary according to the regulation of their respective transport systems, metabolic pathways, rate of utilization by the cells, and their resulting intracellular concentrations.

All plasma amino acid net fluxes that were altered by time after milking exhibited an interaction with lactation 
number (Table 5). In second-lactation cows, net fluxes of isoleucine, lysine, phenylalanine, and threonine tended to follow $(P<0.10)$ similar patterns as whole blood net fluxes, but the first increase of net uptakes occurred between the 4- to 6-h to the 6- to 8-h periods. However, plasma phenylalanine net flux had reached a maximum uptake from the 2- to 4 -h to the 6- to 8-h periods after milking for second-lactation cows. In older cows, a decrease in net fluxes of these amino acids was measured from the 0 - to 2 -h to the 2 - to 6 -h period after milking. It increased during the following $2 \mathrm{~h}$, then declined to its lowest rate at the 8 - to 10 -h period after milking, and then increased again for the 10- to 12 -h period. Plasma net flux of leucine, methionine, and tyrosine were not significantly affected by time after milking averaging $39.7,8.6$, and $11.7 \mathrm{mmol} / \mathrm{h}$, respectively. These interactions between the temporal patterns and lactation number may be explained by the nonmammary venous backflux from the external pudic vein into the mammary vein occurring in cows in third lactation and higher (Thivierge et al., 2000).

Temporal patterns of amino acid net fluxes in whole blood and plasma were slightly different (Table 5). Whole blood amino acid net fluxes were considered to reflect more precisely the temporal variations following milking given that they include red blood cell exchanges. However, when the amino acid concentrations are summed or even taken individually, both whole blood and plasma show some common temporal variations. An increased net flux of the amino acids was reached between the 2to 4 -h and the 6 - to 8-h periods after milking, with the exception of plasma methionine and tyrosine. Thereafter, it decreased consistently between the 8- to 12 -h periods in both whole blood and plasma. Together, the data shows that as the mammary amino acid net fluxes were increased, extensive lipogenesis was simultaneously occurring within the mammary gland, as suggested by the elevated respiratory quotients varying from 2.31 to 2.01 over that period. During the decline in amino acid net fluxes by the end of the 12-h period, the mammary oxygen uptake was increasing by $34 \%$ and the respiratory quotients were concomitantly decreasing from 1.84 to 1.40 , which suggests that lipogenesis was slowing down and that oxidative reactions were promoted. These observations suggest that fatty acid synthesis and amino acid net fluxes are positively correlated. As the rate of fatty acid synthesis increased within the mammary gland, amino acid net fluxes reached a maximum rate. When lipogenesis appeared to decrease concomitant with an increase in oxidation, mammary amino acid net fluxes also decreased to a lower rate. The decreased amino acid net fluxes by the end of the period appear consistent with the regulatory effect of milk accumulation in the udder over time after milking, which decreases protein synthe- sis and increases protein breakdown (Wilde et al., 1987; Rennison et al., 1993). This may involve adjustment of mammary amino acid transport stems (Bequette et al., 2000), given that a down regulation of amino acid transport systems $A$ and L were observed as milk accumulated within rat mammary tissue (Shennan et McNeillie, 1994). These adjustments by the end of the 12-h period may allow for sparing these essential amino acids from extensive oxidation (Black et al., 1990). Glucose uptake by the udder remained constant during the entire $12-\mathrm{h}$ period. This suggests that its oxidation may have increased in the latter period if lactose synthesis was slowing down along with other milk components, as evidenced by the decline in amino acid flux.

A linear regression between whole blood phenylalanine net uptake (Y; mmol/h) and time after milking $(\mathrm{x} ; \mathrm{h})$ was performed to evaluate whether the decreased net uptake measured over time was consistent with the reported decrease in milk yield consecutive to a reduced milking frequency (Van Der Iest and Hillerton, 1989; Bar-Peled et al., 1995; Wilde et al., 1996). The variation of whole blood phenylalanine net flux was chosen because phenylalanine was the amino acid having a linear relationship over time after milking (Table 5). Also, it was considered representative of variations in milk protein secretion given its stoichiometric transfer from blood to milk. Using whole blood fluxes rather than plasma fluxes allowed consideration of red blood cells in phenylalanine exchanges in the analysis. The relationship between whole blood phenylalanine uptake $(\mathrm{y} ; \mathrm{mmol} / \mathrm{h})$ and time after milking $(\mathrm{x} ; \mathrm{h})$ was $\mathrm{Y}=-0.1487+13.26\left(\mathrm{r}^{2}=0.69 ; \mathrm{n}=7\right)$. This equation suggests that if the udder was not milked out during $24 \mathrm{~h}(\mathrm{x}=24)$, the resulting net flux of phenylalanine would decrease from 13.26 to $9.69 \mathrm{mmol} / \mathrm{h}$. This represents a $27 \%$ decrease in phenylalanine net flux over $24 \mathrm{~h}$ from its initial rate immediately after milking, when the measurements made over $12 \mathrm{~h}$ are extrapolated to $24 \mathrm{~h}$. As milk composition is not altered by milking frequency (Van Der Iest and Hillerton, 1989; Bar-Peled et al., 1995; Wilde et al., 1996), changes in milk protein yield should be proportional to changes in milk yield. Once a day milking decreased milk production by 12 to $23 \%$ (Tucker et al., 1961) and by 26\% (Wilde et al., 1990) in dairy cows and by 15\% (Wilde et al., 1996) in dairy goats compared with twice a day milking. Thus, the magnitude of reduction in phenylalanine net flux appears consistent with milk yield reduction reported in previous studies.

\section{Influence of Nonmammary Venous Backflux on Measurements}

The ratios of mammary net uptake to milk output of amino acids from the present study using whole blood or 
Table 6. Mammary amino acid uptake to output ratio using either plasma or whole blood for uptake during a 12 -h period following milking in cows in their second (2 lac) or third and fourth (3 lac) lactation. ${ }^{1}$

\begin{tabular}{|c|c|c|c|c|c|}
\hline & Isoleucine & Leucine & Lysine & Methionine & Threonine \\
\hline \multicolumn{6}{|l|}{ Plasma } \\
\hline $2 \operatorname{lac}^{2}$ & 1.27 & 1.21 & 1.00 & 1.07 & 0.93 \\
\hline $\mathrm{CV}, \%$ & 9.2 & 11.9 & 12.5 & 9.8 & 10.9 \\
\hline$\geq 3 \mathrm{lac}^{3}$ & 1.34 & 1.22 & 1.05 & 1.15 & 0.98 \\
\hline $\mathrm{CV}, \%$ & 11.0 & 9.3 & 9.2 & 7.5 & 6.8 \\
\hline \multicolumn{6}{|c|}{ Whole blood } \\
\hline 2 lac & 1.23 & 1.17 & 0.97 & 1.07 & 0.87 \\
\hline $\mathrm{CV}, \%$ & 2.2 & 15.1 & 6.2 & 7.1 & 14.2 \\
\hline$\geq 3$ lac & 1.35 & 1.19 & 0.99 & 1.01 & 0.91 \\
\hline $\mathrm{CV}, \%$ & 11.9 & 10.4 & 9.3 & 12.4 & 18.3 \\
\hline
\end{tabular}

${ }^{1}$ Phenylalanine and tyrosine are not presented given that their milk output was used for the estimation of blood flow.

$2 \mathrm{n}=3$.

${ }^{3} \mathrm{n}=4$.

plasma for both groups of cows provide values consistent with those reported in the literature (Table 6; Guinard and Rulquin, 1994; Mackle et al. 2000b). The nonmammary blood backflux from the external pudic vein into the mammary vein, demonstrated in the same cows (Thivierge et al., 2000) did not significantly affect this ratio. The impact of possible nonmammary backflux on the temporal variation of amino acid flux was assessed using linear regression with whole blood net flux as the dependent variable (Y; mmol/12 h) and the corresponding milk amino acid output (X; mmol/12 $\mathrm{h}$ ) as the independent variable for each group of cows (Table 7). Whole blood measurements were chosen for testing this hypothesis because it provides a complete overview of mammary amino acid net uptake, including red blood cell contribution. Regression analyses showed that the cows in second lactation exhibited a coefficient of determination ranging from 0.77 to 0.96 for all amino acids excluding threonine, whereas the cows in third lactation and higher exhibited a coefficient of determination ranging from 0.16 to 0.59 , also excluding threonine. This suggests that the use of older cows increases the variability in mammary metabolism measurements. Such observation supports the suggestion that the increased variability of some nutrient mammary net fluxes occurring in older cows could explain the interaction between temporal patterns and lactation number discussed previously. The previous experiment using the same cows demonstrated that the backflux from the external pudic vein diluted the mammary venous concentration of $p$-amino hippuric acid, a nonmetabolizable marker by 14 to $39 \%$ (Thivierge et al., 2000). The resulting alteration in mammary amino acid net fluxes by any backflux depends on the difference in amino acid concentration between the external pudic vein, the mammary vein, and their respective blood flows. Even if the mammary venous concentration of the amino acids studied in older cows provided values appearing consistent with those reported in the literature, the use of older

Table 7. Linear regressions of whole blood amino acid net uptake $(\mathrm{mmol} / 12 \mathrm{~h})$ against the corresponding milk amino acid output (AAO; mmol/12 h) for cows in their second (2 lac) or third and fourth (3 lac) lactation. ${ }^{1}$

\begin{tabular}{llll}
\hline Variable (Y) & $\begin{array}{l}\text { Lactation } \\
\text { number }\end{array}$ & Equation & $\mathrm{R}^{2}$ \\
\hline Isoleucine & 2 lac $^{2}$ & $\mathrm{Y}=-2.46+1.25 \mathrm{AAO}$ & 0.96 \\
Isoleucine & $\geq 3 \mathrm{lac}^{3}$ & $\mathrm{Y}=181.0+0.68 \mathrm{AAO}$ & 0.16 \\
Leucine & 2 lac & $\mathrm{Y}=-392.9+2.33 \mathrm{AAO}$ & 0.82 \\
Leucine & $\geq 3 \mathrm{lac}$ & $\mathrm{Y}=124.9+0.91 \mathrm{AAO}$ & 0.33 \\
Lysine & 2 lac & $\mathrm{Y}=-47.6+1.16 \mathrm{AAO}$ & 0.83 \\
Lysine & $\geq 3$ lac & $\mathrm{Y}=-71.2+1.20 \mathrm{AAO}$ & 0.59 \\
Methionine & 2 lac & $\mathrm{Y}=-16.3+1.28 \mathrm{AAO}$ & 0.77 \\
Methionine & $\geq 3$ lac & $\mathrm{Y}=-28.9+1.28 \mathrm{AAO}$ & 0.46 \\
Threonine & 2 lac & $\mathrm{Y}=31.4+0.69 \mathrm{AAO}$ & 0.27 \\
Threonine & $\geq 3$ lac & $\mathrm{Y}=-320.2+2.28 \mathrm{AAO}$ & 0.28 \\
\hline
\end{tabular}

\footnotetext{
${ }^{1}$ Phenylalanine and tyrosine are not presented given that their milk output was used for the estimation of blood flow.

${ }^{2} \mathrm{n}=3$.

${ }^{3} \mathrm{n}=4$.
} 
cows would likely increase the variability of measurements.

\section{Comparison of Whole Blood and Plasma AV Difference}

The contribution of red blood cells to mammary AV differences of amino acids is controversial. In dairy cattle, it has been shown that plasma is the main precursor pool of amino acids for the mammary gland but red blood cells can contribute to mammary AV difference of amino acids (Hanigan et al., 1991; Mackle et al., 2000b). In dairy goats, red blood cells did not contribute to AV differences across the mammary gland (Bequette et al., 1997). The mammary AV concentration differences of amino acids measured in the present study were averaged over the 12-h period for both whole blood and plasma values and compared (Table 1). Similar average AV differences between whole blood and plasma were observed for phenylalanine, leucine, isoleucine, lysine, and threonine when plasma values were corrected for the volume of red blood cells. The whole blood AV difference of tyrosine was $11.3 \%$ greater than plasma AV difference $(P=0.03)$. Methionine AV difference exhibited an interaction between whole blood or plasma and lactation number $(P=0.01)$. In second-lactation cows, whole blood AV difference was not different from plasma AV difference, while whole blood $\mathrm{AV}$ difference was $11.5 \%$ lower than plasma AV difference in older cows.

Taken together, for the seven amino acids studied, plasma is the primary precursor pool of amino acids for the mammary gland, as observed by other authors (Hanigan et al., 1991; Bequette et al., 1997; Mackle et al., 2000b; Pacheco-Rios et al., 1999). Measurement of amino acid concentration using whole blood or plasma should depend on the objective of the experiment. If a greater accuracy is required, whole blood would provide, in theory, a complete picture of the exchange of amino acids across the udder, although amino acid analyses might be more challenging in whole blood compared with plasma.

\section{CONCLUSIONS}

The present study was designed to improve our knowledge on the regulation of mammary metabolism as the udder gradually fills with milk over time after milking. Overall, the amino acid net uptakes increased from the 2- to 4 -h to the 6 - to 8 -h period after the morning milking. A parallel extensive lipogenesis occurred within the mammary gland during the same period, as suggested by elevated respiratory quotients. Thereafter, the amino acid net fluxes decreased to a lower rate between the 8to $10-\mathrm{h}$ and the 10 - to 12 -h periods after the morning milking. Simultaneously, lipogenesis decreased and oxi- dative processes were promoted, as suggested by lower respiratory quotients and a $34 \%$ increase in mammary oxygen uptake. These findings appear to support the concept that the mammary metabolism is altered over time after milking.

\section{ACKNOWLEDGMENTS}

Appreciation is extended to Jasmin Brochu, Mario Léonard, Paul Luimes, and Sylvie Provencher for their technical assistance. Jocelyne Renaud and André Roy are gratefully acknowledged for their skills in laboratory analyses. Special thanks are also extended to Steve Méthot for statistical advice. We also thank the dairy barn staff of the Dairy and Swine Research and Development Centre, Agriculture and Agri-Food Canada, Lennoxville, for animal care. This work was partly supported by La fédération des producteurs de lait du Québec and by NSERC.

\section{REFERENCES}

Baldwin, R. L. 1968. Estimation of theoretical calorific relationships as a teaching technique. A review. J. Dairy Sci. 51:104-111.

Bar-Peled, U. B., E. Maltz, I. Bruckental, Y. Folman, Y. Kali, H. Gacitua, A. R. Lehrer, C. H. Knight, B. Robinson, H. Voet, and H. Tagari. 1995. Relationship between frequency of milking or suckling in early lactation and milk production of high producing dairy cows. J. Dairy Sci. 78:2726-2736.

Bartels, H., and H. Harms. 1959. Sauerstoffdissoziationskurven des blutes von säugetieren. Pflügers Archiv Bd. 268:S334-365.

Bequette, B. J., F. R. C. Backwell, A. G. Calder, J. A. Metcalf, D. E. Beever, J. C. MacRae, and G. E. Lobley. 1997. Application of a U- ${ }^{13} \mathrm{C}-$ labeled amino acid tracer in lactating dairy goats for simultaneous measurements of the flux of amino acids in plasma and the partition of amino acids to the mammary gland. J. Dairy Sci. 80:2842-2853.

Bequette, B. J., F. R. C. Backwell, C. E. Kyle, A. G. Calder, V. Buchan, L. A. Crompton, J. France, and J. C. MacRae. 1999. Vascular source of phenylalanine, tyrosine, lysine, and methionine for casein synthesis in lactating goats. J. Dairy Sci. 82:362-377.

Bequette, B. J., M. D. Hanigan, A. G. Calder, C. K. Reynolds, G. E. Lobley, and J. C. MacRae. 2000. Amino acid exchange by the mammary gland of lactating goats when histidine limits milk production. J. Dairy Sci. 83:765-775.

Black, A. L., R. S. Anand, M. L. Bruss, C. A. Brown, and J. A. Nakagiri. 1990. Partitioning of amino acids in lactating cows: oxidation to carbon dioxide. J. Nutr. 120:700-710.

Calder, A. G., and A. Smith. 1988. Stable isotope ratio analysis of leucine and ketoisocaproic acid in blood plasma by gas chromatography/mass spectrom. Use of tertiary butyldimethylsilyl derivatives. Mass Spectrom. 2:14-16.

Calder, A. G., K. E. Garden, S. E. Anderson, and G. E. Lobley. 1999. Quantification of blood and plasma amino acids using isotope dilution electron impact gas chromatography/mass spectrometry with U-13C amino acids as internal standard. Rapid Commun. Mass Spectrom. 13:2080-2083.

Canadian Council on Animal Care. I. Guide to care and use of experimental animals, Version 2 Edition. 1993. Bradda Printing Services, Inc., Ottawa, ON.

Cant, J. P., E. J. DePeters, and R. L. Baldwin. 1993. Mammary amino acid utilization in dairy cows fed fat and its relationship to milk protein synthesis. J. Dairy Sci. 76:762-774.

Cant, J. P., and B. W. McBride. 1995. Mathematical analysis of the relationship between blood flow and uptake of nutrients in the mammary glands of a lactating cow. J. Dairy Sci. 62:405-422. 
Dubreuil, P., and H. Lapierre. 1997. Biochemistry reference values for Québec lactating dairy cows, nursing sows, crowing pigs and calves. Can. J. Vet. Res. 61:235-239.

Elia, M., and G. Livesey. 1987. Theory and validity of indirect calorimetry during net lipid synthesis. Am. J. Clin. Nutr. 47:591-607.

Guinard, J., and H. Rulquin. 1994. Effect of graded levels of duodenal infusions of casein on mammary uptake in lactating cows 2 . Individual amino acids. J. Dairy Sci. 77:3304-3315.

Guyton, A. C., and J. E. Hall. 1996a. Overview of the circulation; Medical physics of pressure, flow, and resistance. Pages 161-169 in Textbook of Medical Physiology. Version 9 Edition. WB Saunders Company, Toronto, ON.

Guyton, A. C., and J. E. Hall. 1996b. Regulation respiration. Pages 525-535 in Textbook of Medical Physiology. Version 9 Edition. WB Saunders Company, Toronto, ON.

Hanigan, M. D., C. C. Calvert, E. J. DePeters, B. L. Reis, and R. L. Baldwin. 1991. Whole blood and plasma amino acid uptake by lactating bovine mammary gland. J. Dairy Sci. 74:2484-2490.

Henderson, A. J., and M. Peaker. 1984. Feed-back control of milk secretion in the goat by a chemical in milk. J. Physiol. 351:39-45.

Jensen, R. G. 1995. Handbook of Milk Composition. R. G. Jensen, ed. Academic Press, Toronto, ON.

Kobayashi, R., Y. Shimomura, T. Murakami, N. Nakai, N. Fijitsuka, M. Otsuka, N. Arakawa, K. M. Popov, and R. A. Harris. 1997. Gender difference in regulation of branched-chain amino acid catabolism. Biochem. J. 327:449-453.

Mabjeesh, S. J., C. E. Kyle, J. C. MacRae, and B. J. Bequette. 2000. Lysine metabolism by the mammary gland of lactating goats at two stages of lactation. J. Dairy Sci. 83:996-1003.

Mackle, T. R., D. A. Dwyer, K. L. Ingvartsen, P. Y. Chouinard, D. A. Ross, and D. E. Bauman. 2000a. Effects of insulin and postruminal supply of protein on use of amino acids by the mammary gland for milk protein synthesis. J. Dairy Sci. 83:93-105.

Mackle, T. R., D. A. Dwyer, K. L. Ingvartsen, P. Y. Chouinard, D. A. Ross, and D. E. Bauman. 2000b. Evaluation of whole blood and plasma in the interorgan supply of free amino acids for the mammary gland of lactating dairy cows. J. Dairy Sci. 83:1300-1309.

Mepham, T. B. 1982. Amino acid utilization by the mammary gland. J. Dairy Sci. 65:287-298.

National Research Council. 1989. Nutrient Requirements of Dairy Cattle. Version 6th edition. Natl. Acad. Sci. Washington, DC.

Milliken, G. A., and D. E. Johnson. 1984. Analysis of repeated measures designs for which the usual assumptions hold. Pages 323-340 in Analysis of Messy Data. Volume 1: Designed Experiments. Van Nostrand Reinhold Company, New York.

Oddy, V. H., D. B. Lindsay, and I. R. Fleet. 1988. Protein synthesis and degradation in the mammary gland of lactating goats. J. Dairy Res. 55:143-154.

Pacheco-Rios, D., B. P. Treloar, J. Lee, T. N. Barry, and W. C. McNabb. 1999. Amino acid utilisation by the mammary gland: Whole blood versus plasma free amino acid pools. Proc. N.Z. Soc. Anim. Prod. 59:62-65.

Palmquist, D. L., and T. C. Jenkins. 1980. Fat in lactation: A review. J. Dairy Sci. 63:1-14.

Prosser, C. G., S. R. Davis, V. C. Farr, and P. Lacasse. 1996. Regulation of blood flow in the mammary microvasculature. J. Dairy Sci. 79:1184-1197.

Purser, D. B., T. J. Klopfenstein, and J. H. Cline. 1966. Dietary and defaunation effects upon plasma amino acid concentration in sheep. J. Nutr. 89:226-234.
Rennison, M. E., M. Kerr, C. V. P. Addey, S. E. Handel, M. T. Turner, C. J. Wilde, and R. D. Burgoygne. 1993. Inhibition of constitutive protein secretion from lactating mouse mammary epithelial cells by FIL (feedback inhibitor of lactation), a secreted milk protein. J. Cell Sci. 106:641-648.

SAS User's Guide: Statistics Version 5 Edition. 1985. SAS Inst., Inc., Cary, NC.

Shennan, D. B., and S. A. McNeillie. 1994. Milk accumulation downregulates amino acid uptake via systems $\mathrm{A}$ and L by lactating mammary tissue. Horm. Metab. Res. 26:611.

Stahr, U., R. Hardeland, and J. Hoffman. 1980. Diurnal rythmicity of protein synthesis under controlled amino acid and energy conditions: measurements of ${ }^{3} \mathrm{H}$-leucine incorporation in an in vitro system from rat liver. J. Interdiscipl. Cycle Res. 11:9-17.

Steel, R. G. D., and J. H. Torrie. 1960. Nonlinear regression. Pages 332-345 in Principles and Procedures of Statistics. McGraw-Hill Company, Inc., Toronto, ON.

Strumia, M. M., A. B. Sample, and E. D. Hart. 1954. An improved micro hematocrit method. Am. J. Clin. Pathol. 24:1016-1024.

Thivierge, M. C., D. Petitclerc, J. F. Bernier, Y. Couture, and H. Lapierre. 2000. External pudic venous reflux into the mammary vein in lactating dairy cows. J. Dairy Sci. 83:2230-2238.

Thivierge, M. C., D. Petitclerc, J. F. Bernier, Y. Couture, and H. Lapierre. 2002. Temporal variations of mammary protein metabolism as the udder gradually fills with milk during a 12-h period following milking: leucine kinetics. J. Dairy Sci. 85:(accepted).

Tsai, P., and P. Huang. 1999. Circadian variations in plasma and erythrocyte concentrations of glutamate, glutamine, and alanine in men on a diet without and with added monosodium glutamate. Metabolism 48:1455-1480.

Tucker, H. A., R. P. Reece, and R. E. Mather. 1961. Udder capacity estimates as affected by rate of milk secretion and intramammary pressure. J. Dairy Sci. 44:1725-1732.

Van Der Iest, R. V. D., and J. E. Hillerton. 1989. Short-term effects of frequent milking of dairy cows. J. Dairy Res. 56:587-592.

Verbeke, R., E. Roets, A. M. Massart-Leén, and G. Peeters. 1972. Metabolism of $\left[\mathrm{U}_{-}{ }^{14} \mathrm{C}\right]-\mathrm{L}-$ threonine and $\left[\mathrm{U}_{-}{ }^{14} \mathrm{C}\right]-\mathrm{L}-$ phenylalanine by the isolated perfused udder. J. Dairy Sci. 39:239-250.

Wilde, C. J., D. T. Calvert, A. Daly, and M. Peaker. 1987. The effect of goat milk fractions on synthesis of milk constituents by rabbit mammary explants and on milk yield in vivo. Biochem. J. 242:285-288.

Wilde, C. J., C. V. P. Addey, and C. H. Knight. 1989. Regulation of intracellular casein degradation by secreted milk proteins. Biochim. Biophys. Acta 992:315-319.

Wilde, C. J., and C. H. Knight. 1990. Milk yield and mammary function in goats during and after once-daily milking. J. Dairy Res. 57:441-447.

Wilde, C. J., and M. Peaker. 1990. Autocrine control in milk secretion. J. Agric. Sci. 114:235-238.

Wilde, C. J., C. V.P. Addey, L. M. Boddy, and M. Peaker. 1995. Autocrine regulation of milk secretion by a protein in milk. Biochem. J. 305:51-58.

Wilde, C. J., C. V. P. Addey, and M. Peaker. 1996. Effects of immunization against an autocrine inhibitor of milk secretion in lactating goats. J. Physiol. 491:465-469.

Wurtman, R. J., C. Chou, and C. M. Rose. 1967. Daily rhythm in tyrosine concentration in human plasma: persistence on low-protein diet. Science 158:660-662.

Wurtman, R. J., M. D. C. Rose, C. C. Chou, and F. F. Larin. 1968. Daily rhythms in the concentrations of various amino acids in human plasma. New Engl. J. Med. 279:171-175. 